\title{
DIETARY FATS AND THE DIURNAL SERUM TRIGLYCERIDE LEVELS IN MAN
}

\author{
By PETER T. KUO* AND JOHN C. CARSON $\dagger$ \\ (From the Edward B. Robinette Foundation, Medical Clinics, Hospital of the University of \\ Pennsylvania, Philadelphia, Pa.)
}

(Submitted for publication November 3, 1958; accepted April 10, 1959)

A large number of studies have been made in the attempt to correlate serum cholesterol concentrations in man and in animals with varying amounts and with different kinds of dietary fat. However, only a few observations limited to the effect of diet upon the fasting human serum triglyceride concentration have been reported $(1-4)$. This may be due, at least in part, to the high lability of this serum lipid fraction.

The works of Cunningham and Peters (5), Man and Gildea (6), Elkes, Frazer and Stewart (7), Brun (8), Turner and Steiner (9) and Havel $(10,11)$ clearly demonstrated that variations in both the fat and carbohydrate contents of each meal consistently produced rapid and marked changes in the triglyceride concentration in the human serum, while at the same time, they caused little or no change in the serum cholesterol concentration. Hence, in order to obtain a complete picture of the serum triglyceride level of a given subject, determination of its diurnal variations as well as the fasting level is desirable.

The present investigation is designed to study and compare the 24 hour serum triglyceride curves of the same individual after he is stabilized sequentially on an isocaloric: $a$ ) full diet which contains 100 to $140 \mathrm{Gm}$. of animal fats per day, $b$ ) rice and fruit diet, and $c$ ) corn oil formula diet in which corn oil constitutes 50 to 70 per cent of the total daily caloric intake of the individual.

\section{MATERIAL AND METHOD}

Clinical data of patients studied. Ten cooperative ambulatory subjects, seven males and three females, with various serum lipid concentrations were selected for the

* This work was done during the tenure of an Established Investigatorship of the American Heart Association. This study was supported in part by grants from the Life Insurance Medical Research Fund and the American Heart Association.

$\dagger$ Fellow of the Heart Association of Southeastern Pennsylvania, 1957 and 1958. study. The clinical data and fasting serum triglyceride concentrations of these 10 subjects are summarized in Table I. In order to facilitate presentation of the data, the subjects in this series were classified into four groups according to their serum lipid concentration. Group I is made up of four subjects with normal serum lipid concentrations and showing no clinical evidence of coronary or peripheral arterial disease. In this group M.G. (female) had compensated rheumatic valvular heart disease, and A.P. (female) had lupus erythematosus and pseudobulbar palsy. K.B. and J.J. were two young healthy, male, medical students. In the "pure" hypercholesteremia group, (Group II) were R.J. and J.H. Their total serum cholesterol concentrations were at the 387 to $536 \mathrm{mg}$. per 100 ml. range, but their serum triglyceride concentrations were low. They both had large xanthalesmata on the eyelids and frequent attacks of angina pectoris. Patients R.K. and R.Ka. were classified in Group III. They had hypercholesteremia and mild degrees of hyperlipemia. Their total serum cholesterol concentrations were in the ranges of 950 to 1,200 and 310 to $356 \mathrm{mg}$. per $100 \mathrm{ml}$., respectively. R.K. has large xanthomata on the skin and tendons. R.Ka. had an acute attack of myocardial infarction at the age of 40 and had since been suffering from angina pectoris. Two male patients (J.H. and M.R.) with essential hyperlipemia were placed in Group IV. Both patients had clinical evidence of severe arterial insufficiency of the lower extremities.

Diets and blood samples. The total daily caloric intake of each subject while on full diet was estimated from the history. The full diet was estimated to contain 100 to $140 \mathrm{Gm}$. of animal fat (constituting 40 to 48 per cent of the person's total caloric intake) and 95 to $110 \mathrm{Gm}$. of proteins per day. Thereafter, the patient was allowed to continue for another seven to 10 days on the original diet, with instructions from the dietitian to keep the daily total caloric and fat intake constant and to eat the meals at 8:00 a.m., 12:00 noon and 6:00 p.m. To obtain the first set of diurnal serum triglyceride and other serum lipid curves, starting at 8:00 a.m., venous blood samples were drawn immediately before each meal and every two hours (occasionally three or four hours) throughout 24 hours. At the conclusion of the initial 24 hour study, each of the subjects was put on an isocaloric rice diet containing about $5 \mathrm{Gm}$. of fat and 20 to $30 \mathrm{Gm}$. of proteins and then on a formula diet in which corn oil (Mazola oil ${ }^{1}$ )

\footnotetext{
1 Kindly supplied by the Corn Products Refining Company, Argo, Ill.
} 
TABLE I

Summary of clinical data on subjects studied

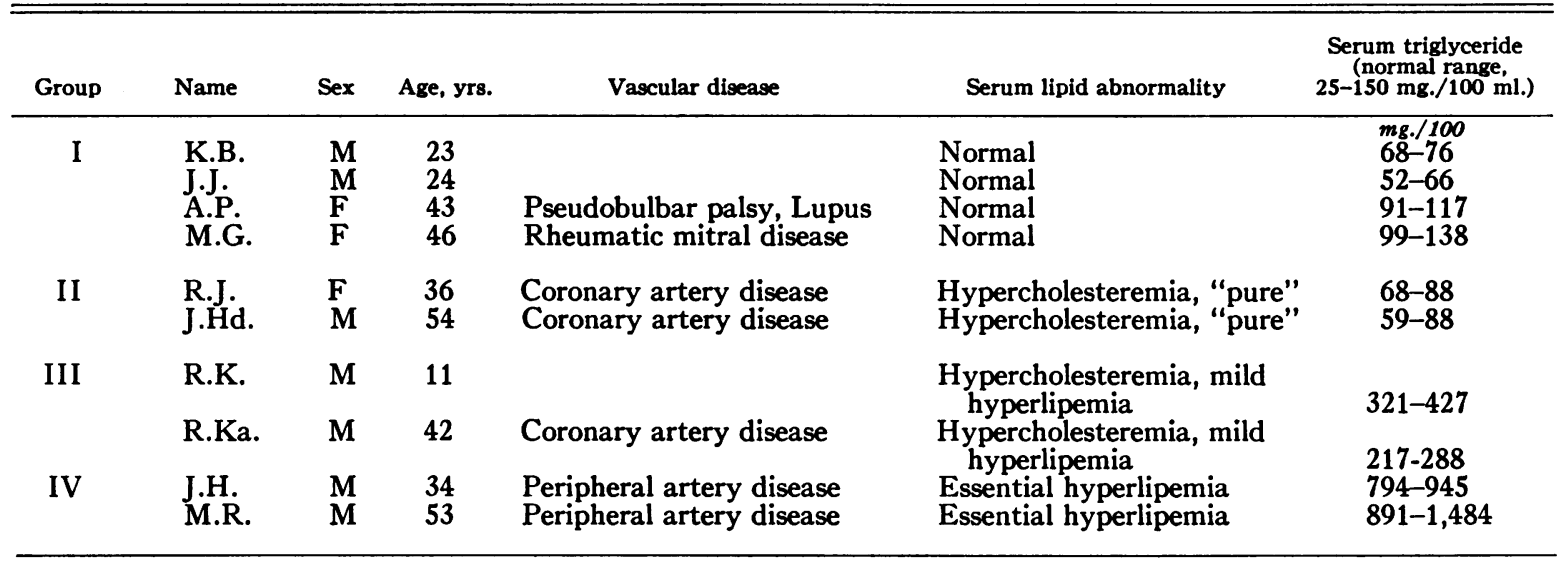

supplied 50 to 70 per cent of the individual's total daily caloric intake (3). This diet contained 120 to $160 \mathrm{Gm}$. of fat and 45 to $60 \mathrm{Gm}$. of proteins. During these special dietary periods, the subjects were encouraged to consume all their daily prescribed rations in order to keep their weight from varying for more than one to two pounds. Fasting blood lipid levels of these subjects were determined at weekly intervals during each dietary period. Significant changes in their serum lipids were generally observed in the second week of each dietary period. It took four to six weeks for the blood lipids of these patients to stabilize on a prescribed diet in preparation for the 24 hour test. Two subjects were kept on rice and fruit diet for 10 and 18 weeks, respectively, before their diurnal blood lipid studies were made. In three patients, the rice and corn oil formula dietary periods were repeated, and then diurnal serum triglyceride curves were again determined.

Total serum cholesterol, phospholipid, total esterified fatty acids, and triglyceride were determined in each of the blood specimens drawn. The methods of Abell, Levy, Brodie and Kendall (12), of Zilversmit and Davis (13),

J.J.

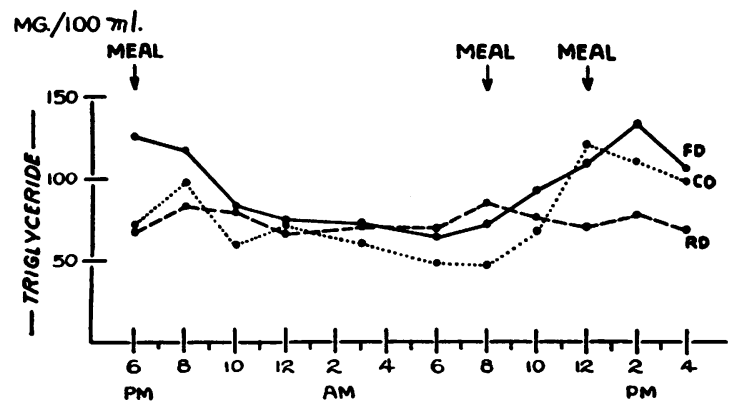

Fig. 1. Diurnal Serum Triglyceride Curves of J.J., a 24 Year Old Healthy, Male, Medical Student Curves F.D., C.O. and R.D. were obtained on full, corn oil formula and rice diets, respectively. of Stern and Shapiro (14) and of Van Handel and Zilversmit (15) were used for the respective determinations. Serum triglyceride concentrations were obtained both by the direct determination and by calculation from cholesterol, phospholipid and total esterified fatty acid values. In each patient, the triglyceride values obtained from the 24 hour test, performed at the end of each dietary period, were utilized to plot a diurnal serum triglyceride curve. The effects of dietary fat intake upon the diurnal serum triglyceride pattern of each of these patients were compared and studied.

\section{RESULTS}

Diurnal serum triglyceride patterns of subjects with normal serum lipids and with "pure" $h y$ percholesteremia (Groups I and II)

The four subjects in Group I each exhibited fairly similar diurnal serum triglyceride curves with full, rice and corn oil formula diets. The effects of dietary changes upon the diurnal serum triglyceride pattern of a young, healthy medical student (J.J.) and of a patient with rheumatic heart disease and normal serum lipids (M.G.) are shown in Figures 1 and 2, respectively. While on full diet (F.D.) the serum triglyceride curves of both subjects begin to rise sharply from their respective fasting levels soon after breakfast. These elevations were maintained throughout the day by meals with high saturated fat content. The postabsorptive lipemias then begin to decrease two to four hours after supper, and the serum triglyceride curves of both subjects are lowered to their respective fasting levels at about 12:00 p.m. When animal fats are omitted from their diet, and 


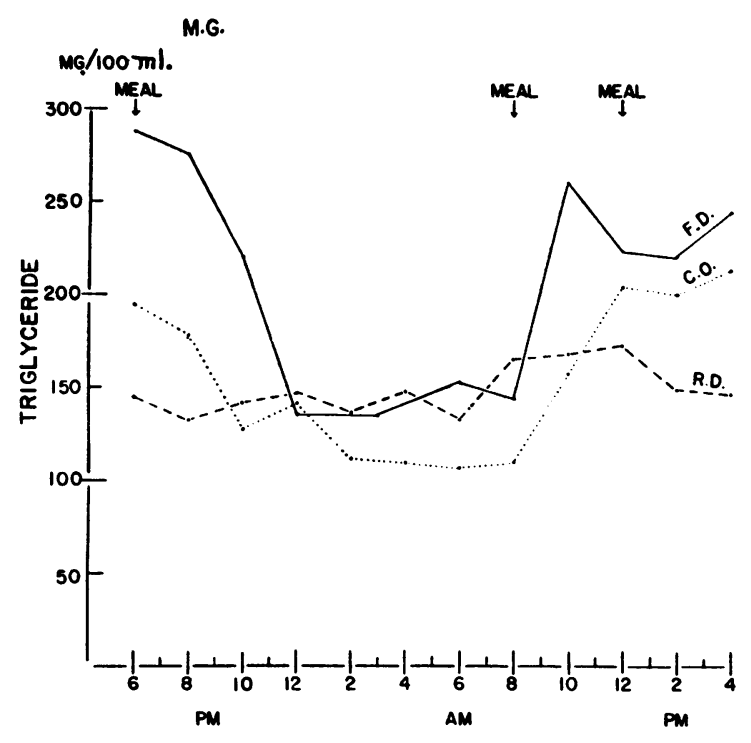

Fig. 2. Diurnal Serum Triglyceride Curves of M.G., a 46 Year Old Female with Normal Serum Lipid Values and Compensated Rheumatic Mitral Disease

Curves F.D., C.O. and R.D. were obtained on full, corn oil formula and rice diets, respectively.

70 per cent of their total daily caloric intake is in the form of corn oil (C.O.), their serum triglyceride curves show more gradual rises to smaller lipemic peaks than those observed during the full diet periods. These milder postabsorptive lipemias are again maintained throughout the day. But, soon after supper, the curves drop rapidly to their respective low fasting levels (20 to $40 \mathrm{mg}$. per

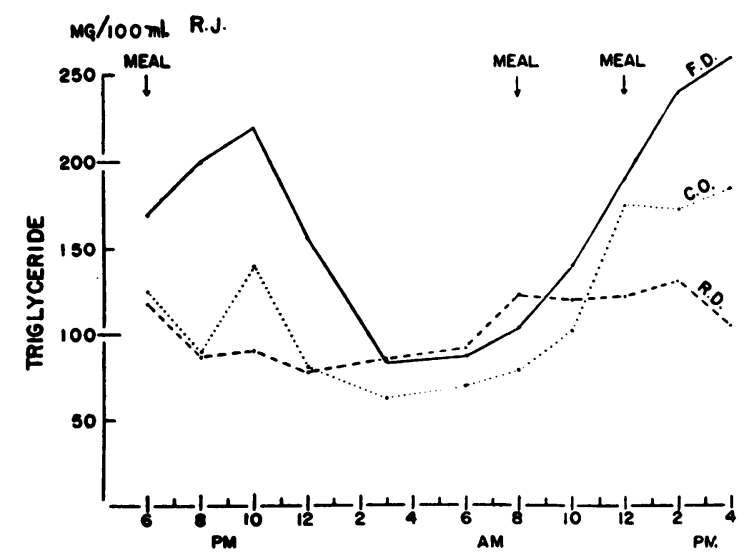

Fig. 3. Diurnal Serum Triglyceride Curves of R.J., a Young Female with Ischemic Heart Disease AND "PuRE" HyPercholesteremia

Curves F.D., C.O. and R.D. were obtained on full, corn oil formula and rice diet, respectively.
$100 \mathrm{ml}$. lower than the respective fasting full diet levels). On rice diet (R.D.), their serum triglyceride curves show little fluctuation with meals. After 14 hours of fasting, slight rises in their serum triglyceride concentrations are observed. The fasting baselines of these relatively flat curves run at almost exactly the same level as that of the full diet curves, and they are about 20 to $40 \mathrm{mg}$. per $100 \mathrm{ml}$. higher than those of the respective corn oil feeding periods.

The patients with "pure" hypercholesteremia and low serum triglyceride concentration show essentially the same diurnal triglyceride patterns in response to these dietary manipulations. The diurnal serum triglyceride curves obtained from R.J. with rice diet and high saturated and unsaturated fat intakes are shown in Figure 3.

The diurnal serum triglyceride level studies with rice and corn oil formula diets were repeated in M.G. and R.J. three to four months after the completion of the initial series of determinations.

Excellent reproductions of the original rice and corn oil serum triglyceride patterns were obtained in each of the two patients. It is of interest to note that both the fasting and the postprandial serum triglyceride concentrations of the two young medical students were lower than those observed in the four older patients having either normal serum lipid concentrations or "pure" hypercholesteremia.

\section{Diurnal serum triglyceride pattern of patients with hypercholesteremia and mild hyperlipemia}

Two patients with hypercholesteremia and mild degrees of hyperlipemia had similar diurnal serum triglyceride patterns in response to changes in their dietary fat, carbohydrate and protein intake. Figure 4 shows the diurnal serum triglyceride curves of R.Ka., while consuming full, rice and corn oil formula diets.

In comparison with the subjects in Group I and II, while on full diet (F.D.), the patient's serum triglyceride curve rose abruptly from a high fasting level of $225 \mathrm{mg}$. per $100 \mathrm{ml}$. fasting level to about $500 \mathrm{mg}$. per $100 \mathrm{ml}$. two hours later. Subsequently, the curve shows two lipemic peaks, one following lunch and the other after supper. The postabsorptive lipemia is prolonged and is "cleared" by 4:00 a.m. The curve then remains at this relatively low level until the next 


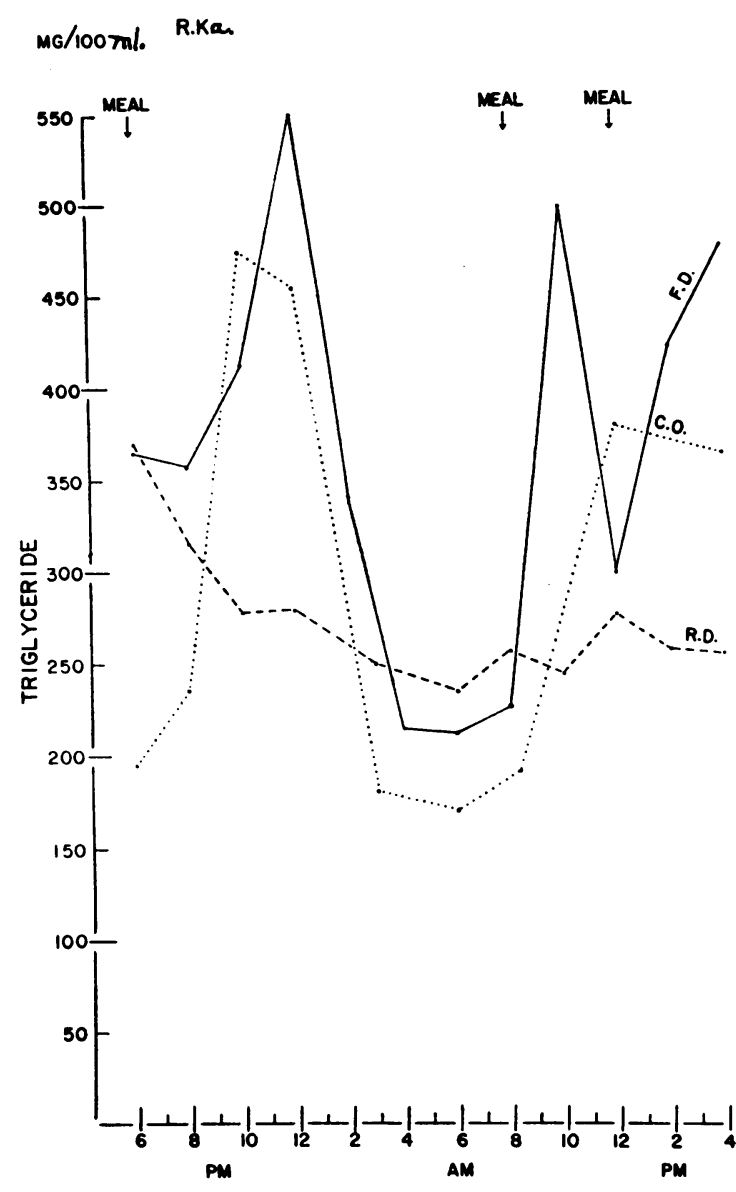

Fig. 4. Diurnal Serum Triglyceride Curves of R.KA. on Full (F.D.), Corn Oil Formula (C.O.) and RICE (R.D.) DIETS

Patient had ischemic heart disease and moderate elevation of serum cholesterol and triglyceride levels.

breakfast. Like the subjects in Group I and II, with corn oil feeding (C.O.), the rise in the serum triglyceride curve following breakfast is more gradual and reaches a lower peak than that of the postabsorptive curve obtained on him while he consumed a full diet. However, the lipemia is quite marked and prolonged in the early evening. The curve dips to a low level (30 to $40 \mathrm{mg}$. per $100 \mathrm{ml}$. lower than the fasting values of the full diet curve) in the early morning. It is then maintained at 170 to $180 \mathrm{mg}$. per $100 \mathrm{ml}$. level until the following meal. The rice diet curve (R.D.) shows no marked postabsorptive fluctuations. It is interesting to point out that, while the patient was on rice diet, the serum triglyceride levels measured during the fasting hours were considerably higher than those taken when the patient was either on a full diet or on a high corn oil intake. In spite of the very low fat content of the rice and fruit diet, the serum triglyceride curve shows a moderate elevation in the early evening.

Diurnal serum triglyceride of hyperlipemic subjects

Alterations in the diurnal serum triglycerides with dietary changes in the two patients with es-

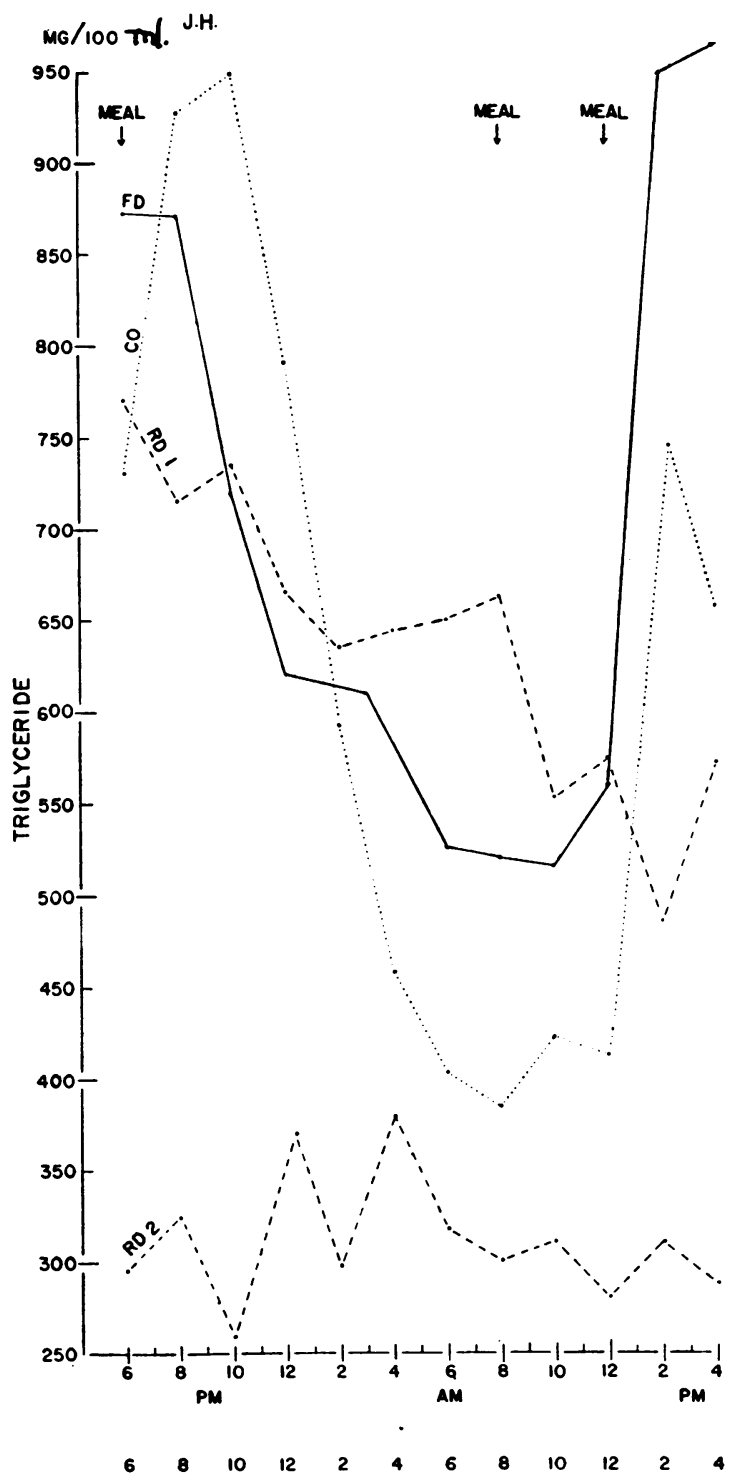

Fig. 5. Diurnal Serum Triglyceride Curves of J.H., a Hyperlipemic with Peripheral Arterial OcClusive Disease

Curves F.D., C.O. and R.D.1 and R.D.2 were obtained on full, corn oil and rice (Periods 1 and 2) diets, respectively. 
sential hyperlipemia were quite similar. Figure 5 shows the studies obtained from J.H. The full diet curve (F.D.) shows that his serum triglyceride rises sharply from a highly elevated fasting level following breakfast to reach a very high level at 12:00 noon. This high serum triglyceride concentration is maintained by the subsequent meals. The curve then returns to a high baseline at 6:00 a.m. and remains unchanged before the next breakfast. While on corn oil (C.O.), his fasting serum triglyceride level is very much lower than those obtained during the full diet or rice diet periods. The rise of the corn oil curve after breakfast is somewhat slower and lower than that of the full diet curve, but the "clearing" of postabsorptive lipemia is markedly delayed. On changing to rice $\operatorname{diet}\left(\mathrm{R} . \mathrm{D}_{1}\right.$ ) for four weeks, the serum triglyceride curve shows a high fasting level. The curve shows some lowering following breakfast and lunch and rises to a peak level before supper.

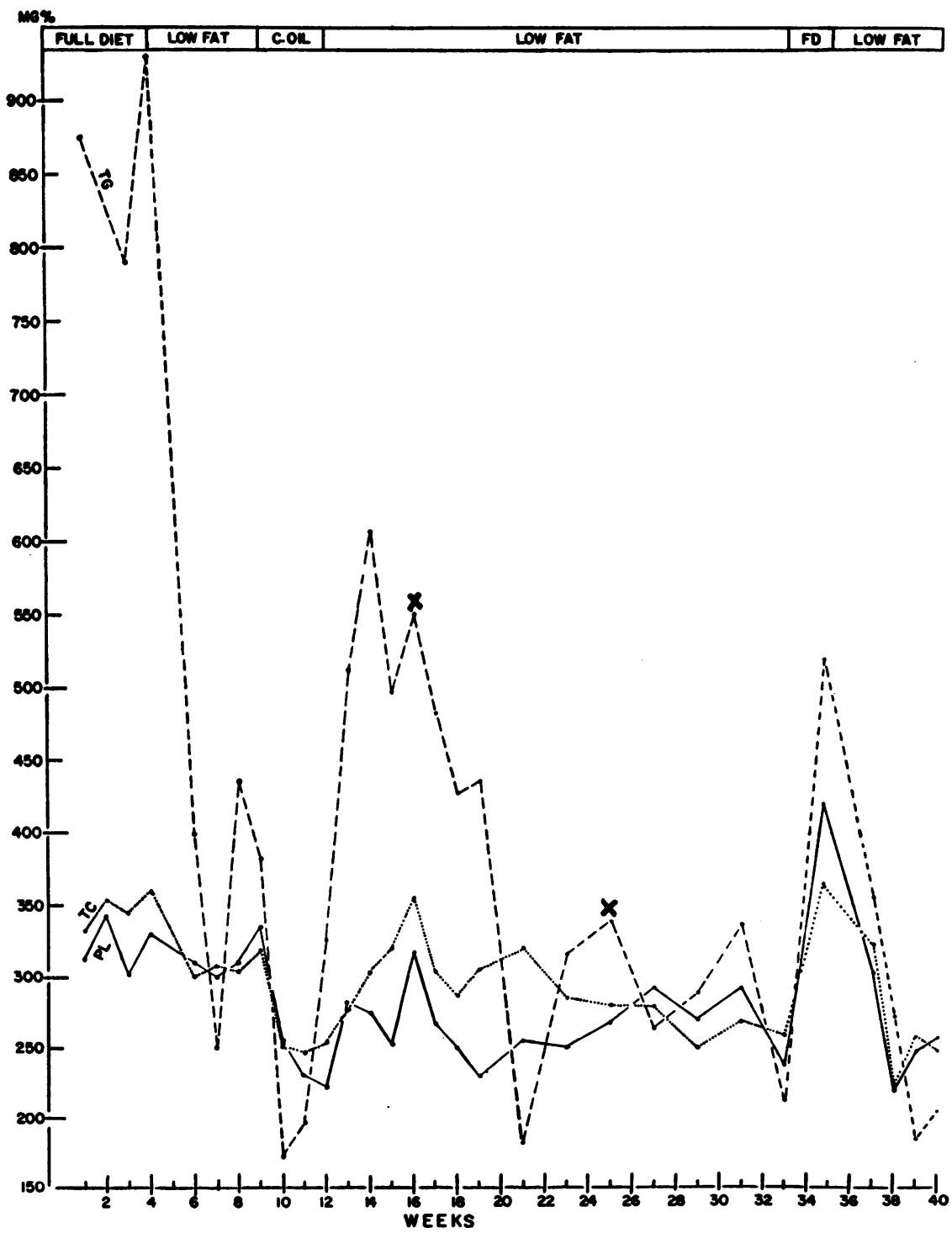

Fig. 6. Changing Serum Triglyceride (T.G.), Total Cholesterol (T.C.) and Phospholipid (P.L.) Levels of J.H. with Dietary Changes

F.D. indicates full diet. $\mathrm{X}$ and $\mathrm{XX}$ indicate the times at which the diurnal triglyceride curves R.D.1 and R.D.2 of Figure 5 were obtained. 
TABLE II

Effect of diet on serum cholesterol and phospholipid concentrations of the subjects studied

\begin{tabular}{|c|c|c|c|c|c|c|c|c|c|c|c|c|c|}
\hline \multirow[b]{2}{*}{ Group } & \multirow[b]{2}{*}{ Name } & \multicolumn{6}{|c|}{ Total cholesterol } & \multicolumn{6}{|c|}{ Phospholipids } \\
\hline & & $1^{*}$ & $1 \mathrm{At}$ & $2 *$ & 2At & $3^{*}$ & 3AT & 1 & $\mathbf{1 A}$ & 2 & $2 \mathrm{~A}$ & 3 & $\mathbf{3 A}$ \\
\hline \multirow[t]{2}{*}{ I } & $\begin{array}{l}\text { K.B. } \\
\text { J.J. } \\
\text { A.P.t }\end{array}$ & $\begin{array}{l}167 \\
144 \\
275\end{array}$ & $\begin{array}{l}10 \\
19 \\
34\end{array}$ & \multirow{2}{*}{$\begin{array}{r}119 \\
113 \\
222 \\
\mathrm{~b} 212 \\
223\end{array}$} & \multirow{2}{*}{$\begin{array}{l}16 \\
17 \\
23 \\
30 \\
31\end{array}$} & \multirow{2}{*}{$\begin{array}{r}117 \\
109 \\
-197 \\
\text { b204 } \\
198\end{array}$} & \multirow{2}{*}{$\begin{array}{l}15 \\
17 \\
31 \\
25 \\
34\end{array}$} & $\begin{array}{l}182 \\
181 \\
203\end{array}$ & $\begin{array}{l}30 \\
32 \\
43\end{array}$ & \multirow{2}{*}{$\begin{array}{r}135 \\
136 \\
\mathbf{2} 199 \\
\text { b189 } \\
253\end{array}$} & \multirow{2}{*}{$\begin{array}{l}18 \\
20 \\
30 \\
32 \\
35\end{array}$} & \multirow{2}{*}{$\begin{array}{r}123 \\
132 \\
\times 183 \\
\text { b175 } \\
219\end{array}$} & \multirow{2}{*}{$\begin{array}{l}27 \\
20 \\
53 \\
38 \\
55\end{array}$} \\
\hline & M.G. & 257 & 32 & & & & & 310 & 95 & & & & \\
\hline \multirow[t]{2}{*}{ II } & R.J. $\ddagger$ & 435 & 67 & \multirow{2}{*}{$\begin{array}{r}.319 \\
\text { b326 } \\
361\end{array}$} & \multirow{2}{*}{$\begin{array}{l}48 \\
45 \\
44\end{array}$} & \multirow{2}{*}{$\begin{array}{r}254 \\
\text { b270 } \\
308\end{array}$} & \multirow{2}{*}{$\begin{array}{l}\mathbf{5 9} \\
\mathbf{5 7} \\
40\end{array}$} & 303 & 83 & \multirow{2}{*}{$\begin{array}{r}209 \\
\text { b218 } \\
232\end{array}$} & \multirow{2}{*}{$\begin{array}{l}40 \\
57 \\
62\end{array}$} & \multirow{2}{*}{$\begin{array}{r}178 \\
b_{183} \\
206\end{array}$} & \multirow{2}{*}{$\begin{array}{l}73 \\
59 \\
67\end{array}$} \\
\hline & J.Hd. & 470 & 59 & & & & & 285 & 68 & & & & \\
\hline III & $\begin{array}{l}\text { R.K. } \\
\text { R.Ka. }\end{array}$ & $\begin{array}{l}987 \\
325\end{array}$ & $\begin{array}{r}104 \\
55\end{array}$ & $\begin{array}{l}673 \\
253\end{array}$ & $\begin{array}{l}80 \\
30\end{array}$ & $\begin{array}{l}891 \\
250\end{array}$ & $\begin{array}{r}108 \\
40\end{array}$ & $\begin{array}{l}658 \\
249\end{array}$ & $\begin{array}{r}104 \\
65\end{array}$ & $\begin{array}{l}407 \\
242\end{array}$ & $\begin{array}{l}28 \\
67\end{array}$ & $\begin{array}{l}512 \\
238\end{array}$ & $\begin{array}{l}80 \\
44\end{array}$ \\
\hline \multirow[t]{2}{*}{ IV } & J.H.‡ & 383 & 93 & \multirow{2}{*}{$\begin{array}{r}\mathbf{3} 321 \\
\text { b271 } \\
259\end{array}$} & \multirow{2}{*}{$\begin{array}{l}42 \\
40 \\
39\end{array}$} & \multirow{2}{*}{$\begin{array}{r}245 \\
\text { b233 } \\
239\end{array}$} & \multirow{2}{*}{$\begin{array}{l}44 \\
31 \\
54\end{array}$} & 420 & 118 & \multirow{2}{*}{$\begin{array}{r}297 \\
\text { b220 } \\
251\end{array}$} & \multirow{2}{*}{$\begin{array}{l}50 \\
35 \\
30\end{array}$} & \multirow{2}{*}{$\begin{array}{r}248 \\
b 254 \\
211\end{array}$} & \multirow{2}{*}{$\begin{array}{l}78 \\
59 \\
41\end{array}$} \\
\hline & M.R. & 342 & 63 & & & & & 458 & 80 & & & & \\
\hline
\end{tabular}

* Serum total cholesterol and phospholipid values in $\mathrm{mg}$. per $100 \mathrm{ml}$. with full, rice and corn oil formula diets, re spectively.

$\dagger$ Diurnal varixtions of levels (maximal-minimal differential) with full, rice and corn oil formula diets, respectively.

$\ddagger$ Two sets of serum lipid values obtained from A.P., R.J. and J. H.while on rice diet and corn oil formula diets are presented in Columns $2,2 \mathrm{~A}$, and 3 and $3 \mathrm{~A}$.

Thereafter, it drifts slowly downwards and finally settles at a high fasting level between 2:00 and $8: 00$ a.m.

Following the initial 24 hour test, 60 to $65 \mathrm{Gm}$. of Amigen ${ }^{(8)}$ powder $^{2}$ (protein hydrolysate) three times a day was added to the rice and fruit diet of this patient. A second 24 hour serum triglyceride study was performed on him six weeks later. The results are presented graphically (R.D.2). Except for two minor elevations at 12:00 midnight and 4:00 a.m., respectively, the curve is quite flat and low.

The effect of dietary changes upon the fasting serum lipid levels of this hyperlipemic patient, J.H., is shown in Figure 6. While on full diet with high saturated fat intake, his fasting serum triglyceride concentration ranged between 794 to $945 \mathrm{mg}$. per $100 \mathrm{ml}$. A precipitous drop in his serum lipid concentration, particularly that in his serum triglyceride level, was observed when he was placed on rice (low fat) diet. The subsequent period of corn oil feeding apparently caused a further lowering of his serum lipid values. However, on returning to the rice (low fat) diet, the patient developed a neutral-fat lipemia which lasted for 10 weeks. The first 24 hour blood

\footnotetext{
2 Kindly supplied by Dr. E. A. Hawk, Mead Johnson Company, Evansville, Ind.
}

lipid study with rice diet (R.D.. in Figure 5) was performed on him during this lipemic period (X). This lipemic state improved coincidental with the addition of 60 to $65 \mathrm{Gm}$. of Amigen ${ }^{\circledR}$ powder per day to the rice diet. The second 24 hour serum triglyceride study (R.D..$_{2}$ in Figure 4) was performed on him at this time (XX).

\section{Serum cholesterol and phospholipids}

The 24 hour mean and the diurnal fluctuations in the total serum cholesterol and phospholipid values obtained in these patients during this investigation are tabulated in Table II. Mean 24 hour serum total cholesterol and phospholipid values of each patient obtained with full, rice and corn oil formula diets are listed in Columns 1, 2 and 3 , respectively. The diurnal maximal-minimal differential of their serum cholesterol and phospholipid values observed with full, rice and corn oil feedings are shown in Columns 1A, 2A and $3 \mathrm{~A}$, respectively.

On changing from a full diet to rice diet, the mean total serum cholesterol concentrations of these subjects showed an average drop of 23.3 per cent (range, 13.2 to 31.8 per cent). And, their mean serum cholesterol levels observed during the periods of corn oil formula diet were on the average 27.0 per cent (with a range of 9.7 to 
36.0 per cent) lower than those obtained during the full diet periods. Somewhat similar lowerings of their mean serum phospholipid values were also observed. With the changes in the diet, their mean serum phospholipid levels were 26.5 per cent (range, 1.8 to 47.0 per cent) and 29.1 per cent (range, 4.4 to 53.8 per cent) with rice and corn oil formula diets, respectively, lower than values observed on them during the full diet periods.

A high corn oil intake appears to be more effective than rice diet in lowering the serum cholesterol and phospholipids level in five subjects. However, the degree of effectiveness of corn oil in lowering the serum lipids varied a great deal from one subject to another. In three subjects, the serum cholesterol and phospholipid concentrations were not significantly lowered on changing from rice and fruit diet to corn oil formula feeding.

In the case of R.K., his serum phospholipid and cholesterol increased more than $100 \mathrm{mg}$. per 100 ml. with corn oil feeding for 12 weeks.

Like the serum triglyceride concentrations, the serum cholesterol and phospholipid levels of these subjects also showed a tendency to diurnal variations. In these subjects, the lowest points of their lipid curves were usually inscribed between the hours of 4 and 8 a.m., and the highest levels were registered between 2 to 9 p.m. The 24 hour maximal-minimal differential of their serum cholesterol and phospholipids concentrations ranged between 15 to $108 \mathrm{mg}$. per $100 \mathrm{ml}$. and 18 to $118 \mathrm{mg}$. per $100 \mathrm{ml}$., respectively, in these patients. Diurnal fluctuations of these serum lipid levels were particularly prominent in patients with extreme degrees of hypercholesterolemia and hyperphosphatemia, while ingesting a full diet with a high saturated fat intake. The lipid curves tended to flatten out after the serum lipid concentrations of these subjects were lowered by the use of rice and corn oil formula diets.

\section{DISCUSSION}

Much interest has recently been aroused in the study of serum triglyceride concentrations by the demonstration that hyperlipemia may accelerate blood clotting (16-20), increase blood viscosity as well as the adhesiveness and aggregation of red blood cells (21-23), and aggravate myocardial ischemia (24). An increased coagulability of the blood was also observed in patients with ischemic heart disease, ingesting a full diet. The platelet stickiness was found to decrease with the use of rice-fruit diet $(25,26)$. Recently, Albrink and Man (4) have reported a better correlation between fasting serum triglyceride concentration and the incidence of clinical atherosclerosis than that of serum cholesterol levels. It has been shown that both fat and carbohydrate ingestion can cause a rapid and profound change in the concentration of this labile serum lipid fraction (511). Consequently, adequate information of the dietary effect upon the serum triglyceride level in a given patient can only be obtained by studying the changing concentrations of the lipid in his blood throughout the 24 hour period.

In the attempt to elicit evidence of a defective lipid metabolism in human atherosclerosis, a number of fat tolerance tests have been employed by various investigators to study the nature of postabsorptive lipemia in atherosclerotic subjects. Although certain abnormalities in the postprandial lipemia pattern have been observed in the majority of patients with clinical atherosclerosis, however, the data obtained were beclouded by a number of uncontrolled factors. It must be pointed out that, in addition to the individual's fat tolerance, his previous dietary habit (10), the kind and the amount of fat given, as well as glucose, sugars and carbohydrate used in the test meal $(11,27-30)$ may profoundly affect his postprandial serum triglyceride curve. In the present study a diurnal serum triglyceride curve was obtained in each of the subjects after he had been stabilized in a given dietary regimen. This experimental design would tend to eliminate most of the complicating factors mentioned; and it would permit a comparative study of: $a$ ) differences in fat tolerance between one individual and another, $b$ ) differences in postabsorptive lipemias caused by ingestion of large amounts of saturated (typical American diet) and unsaturated fat [corn oil formula diet as described by Ahrens and coworkers (3)].

The data obtained from the study of this small series of subjects indicate that while on corn oil formula diet, the postprandial serum triglyceride elevation in each of the subjects, with normal serum lipid concentration and with "pure" hypercho- 
lesteremia, was significantly lower and briefer than the elevation obtained while he was on a full diet. These differences in the effect of saturated and unsaturated dietary fat upon the serum triglyceride became progressively less evident in patients with increasing degrees of hyperlipemia. It is well known that the measured serum triglyceride level represents the resultant of triglyceride absorption into, and of its removal from, one's blood stream. Since there is no apparent evidence for a disturbed fat absorption from the gastrointestinal tract of any of these patients, it is perhaps reasonable to assume that in certain subjects, particularly in the hypercholesteremics, the rate of triglyceride removal from the blood stream is probably increased when they are consuming a diet with high unsaturated fat content.

Of further interest is the observation of a progressively rising serum triglyceride level before supper in hyperlipemic patients, while consuming a rice and fruit diet, which contains only about 5 $\mathrm{Gm}$. of fat per day. The mechanism of this predinner rise of serum triglyceride concentration is not well understood at the present time. Since the body store of carbohydrate is limited, triglycerides (its lability may be increased in patients with hyperlipemia) may have been mobilized from the fat depot to satisfy the energy requirements of the patient when the availability of carbohydrate for energy metabolism is decreased. Havel, in his study of effects of glucose administration on very low density lipoprotein of clinically normal men, has suggested that its concentration appears to depend on the availability of carbohydrate for energy production (10).

The chief interest of this investigation is centered on the observation that certain patients would exhibit a lipemia with severe restriction of daily dietary fat intake (1-4). On this basis, Ahrens and his associates (3) have repeatedly cautioned against the use of a low fat diet in patients with ischemic heart disease. It should be emphasized, however, that all of their observations were confined to blood lipid determinations made in the fasting state. Our data showed that in a nonhyperlipemic subject, the fasting serum triglyceride level was not significantly affected by extreme changes made in the dietary fat content. But in a hyperlipemic patient, the fasting serum triglyceride level may show a considerable eleva- tion with the prolonged use of rice diet thus confirming the observations made by Hatch, Abell and Kendall (2), Ahrens and associates (3) and Albrink and Man (4). However, if this comparative study of serum triglyceride concentration with changing dietary fat content were extended to include the whole postabsorptive period (8:00 to 2:00 a.m.) of the day, it would be difficult to demonstrate that the addition of large quantities of corn oil to the diet had actually lowered the diurnal serum triglyceride levels of the patient. Recently, McDonald and Edgill have demonstrated a decrease in platelet adhesiveness in patients with ischemic heart disease while consuming a rice and fruit diet (26). Although no attempt has been made by these investigators to correlate their findings with serum triglyceride concentrations of their patients, it is nevertheless valid to assume that some of their patients must have developed lipemia with the rice diet; and that this fasting lipemia of fat restriction type may exert totally different physiologic effects from that of postabsorptive type of lipemia following the ingestion of a high fat meal.

The mechanism of the fasting lipemia with rice diet is not entirely understood. Hatch, Abell and Kendall (2) suggested that the phenomenon may be due to the conversion of carbohydrate into fat when food intake exceeds energy requirements. The possibility of other metabolic factors including an increased triglyceride mobilization also being involved in the production of this peculiar type of lipemia remains to be elucidated.

In all subjects the serum triglyceride concentrations obtained by calculation from cholesterol, phospholipid and total esterified fatty acid values were consistently lower than those obtained by the direct method. The amount of difference observed between the two methods varies considerably from one subject to another. Negative values were obtained by the calculation method in both hypercholesteremic patients (R.J. and J.Hd.). Hence, only the values obtained by the direct method were reported. Entenman (31) suggested and Reinhold (32) recently demonstrated that this underestimation of triglycerides by calculation may be due to the fact that various cholesterol esters yield low molar estimation values. Moreover, a portion of phospholipid is present in plasma as sphingomyelin which con- 
tains only one fatty acid molecule per mole of phosphorus.

\section{SUM MARY}

1. The diurnal variations in serum triglyceride, cholesterol and phospholipid levels of a series of 10 subjects on isocaloric full, rice and fruit and 50 to 70 per cent corn oil formula diets were determined.

2. In all subjects the diurnal serum cholesterol and phospholipid variations were minimal.

3. In four subjects with normal lipid metabolism and two patients with "pure" hypercholesteremia the postprandial serum triglyceride elevations were lower and briefer while on corn oil diet than on a typical American (full) diet.

4. These differences in the effects of unsaturated and saturated dietary fats upon one's postprandial serum triglyceride concentration became progressively less evident in four patients with increasingly severe degrees of hyperlipemia.

5. While on rice and fruit diet, the fasting serum triglycerides of the nonlipemic subjects were only slightly higher than their respective fasting levels measured during the full and corn oil formula dietary periods. But the mean diurnal serum triglyceride levels of these subjects were low with the rice and fruit diet.

6. In hyperlipemic patients, significant inincreases in their fasting serum triglyceride concentrations were observed, following the change from high fat diets to the rice and fruit diet.

\section{ACKNOWLEDGMENT}

We are indebted to Miss Miriam R. Nichols, dietitian, Hospital of the University of Pennsylvania, for all the dietary advice and arrangements. Mr. George MacNeal helped us on the serum triglyceride determinations.

\section{REFERENCES}

1. Watkin, D. M., Froeb, H. F., Hatch, F. T., and Gutman, A. B. Effects of diet in essential hypertension. II. Results with unmodified Kempner rice diet in fifty hospitalized patients. Amer. J. Med. 1950, 9, 441.

2. Hatch, F. T., Abell, L. L., and Kendall, F. E. Effects of restriction of dietary fat and cholesterol upon serum lipids and lipoproteins in patients with hypertension. Amer. J. Med. 1955, 19, 48.

3. Ahrens, E. H., Jr., Insull, W., Jr., Blomstrand, R.,
Hirsch, J., Tsaltas, T. T., and Peterson, M. L. The influence of dietary fats on serum-lipid levels in man. Lancet 1957, 1, 943.

4. Albrink, M. J., and Man, E. B. Serum triglycerides in coronary artery disease. Arch. intern. Med. 1959, 103, 4.

5. Cunningham, R. N., and Peters, B. A. Chemical nature of the ultramicroscopic particles of serum. Biochem. J. 1938, 32, 1482.

6. Man, E. B., and Gildea, E. F. The effect of the ingestion of large amount of fat and of a balanced meal on the blood lipids of normal man. J. biol. Chem. 1932, 99, 61.

7. Elkes, J. J., Frazer, A. C., and Stewart, H. C. The composition of particles seen in normal human blood under dark-ground illumination. J. Physiol. (Lond.) 1939, 95, 68.

8. Brun, G. Changes in the lipide contents of serum in patients with manic-depressive psychosis. Acta psychiat. (Kbh.) 1940, Suppl. 22.

9. Turner, K. B., and Steiner, A. A long term study of the variation of serum cholesterol in man. J. clin. Invest. 1939, 18, 45.

10. Havel, R. J. Early effects of fasting and of carbohydrate ingestion on lipids and lipoproteins of serum in man. J. clin. Invest. 1957, 36, 855.

11. Havel, R. J. Early effects of fat ingestion on lipids and lipoproteins of serum in man. J. clin. Invest. 1957, 36, 848.

12. Abell, L. L., Levy, B. B., Brodie, B. B., and Kendall, F. E. Simplified method for estimation of total cholesterol in serum and demonstration of its specificity. J. biol. Chem. 1952, 195, 357.

13. Zilversmit, D. B., and Davis, A. K. Microdetermination of plasma phospholipids by trichloracetic acid precipitation. J. Lab. clin. Med. 1950, 35, 155.

14. Stern, I., and Shapiro, B. Rapid and simple method for determination of esterified fatty acids and for total fatty acids in blood. J. clin. Path. 1953, 6, 158.

15. Van Handel, E., and Zilversmit, D. B. Micromethod for the direct determination of serum triglycerides. J. Lab. clin. Med. 1957, 50, 152.

16. Duncan, G. G., and Waldron, J. M. The effect of ingested fat on blood coagulation. Trans. Ass. Amer. Phycns 1949, 62, 179.

17. Fullerton, H. W., Davie, W. J. A., and Anastasopoulos, G. Relationship of alimentary lipemia to blood coagulability. Brit. med. J. 1953, 2, 250.

18. Poole, J. C. F. The significance of chylomicra in blood coagulation. Brit. J. Haemat. 1955, 1, 229.

19. O'Brien, J. R. Relation of blood-coagulation to lipaemia. Lancet 1955, 2, 690.

20. Buzina, R., and Keys, A. Blood coagulation after a fat meal. Circulation 1956, 14, 854.

21. Cullen, C. F., and Swank, R. L. Intravascular aggregation and adhesiveness of the blood elements associated with alimentary lipemia and ingestions 
of large molecular substances. Circulation 1954, 9, 335.

22. Swank, R. L. Effect of high fat feedings on viscosity of the blood. Science 1954, 120, 427.

23. Swank, R. L. Effects of fat on blood viscosity in dogs. Circulat. Res. 1956, 4, 579.

24. Kuo, P. T., and Joyner, C. R., Jr. Angina pectoris induced by fat ingestion in patients with coronary artery disease. J. Amer. med. Ass. 1955, 158, 1008.

25. McDonald, L., and Edgill, M. Coagulability of the blood in ischemic heart disease. Lancet 1957, 2, 457.

26. McDonald, L., and Edgill, M. Dietary restriction and coagulability of the blood in ischaemic heart-disease. Lancet 1958, 1, 996.
27. Waldron, J. M., and Duncan, G. G. Variability of the rate of coagulation of whole blood. Amer. J. Med. 1954, 17, 365.

28. Rony, H. R., and Ching, T. T. Studies on fat metabolism. II. The effect of certain hormones on fat transport. Endocrinology 1930, 14, 355.

29. Albrink, M. J., and Man, E. B. Effect of carbohydrate ingestion on postprandial lipemia. Clin. Res. Proc. 1956, 4, 121.

30. Man, E. B., and Albrink, M. J. Serum lipids in different phases of carbohydrate metabolism. Yale J. Biol. Med. 1956, 29, 316.

31. Entenman, C. Preparation and determination of higher fatty acids in Method of Enzymology, S. P. Colowick and N. O. Kaplan, Eds. New York, Academic Press Inc., 1957, vol. 3, p. 323.

32. Reinhold, J. E. Personal communication. 